\title{
Luminiszentzia, baliabide aproposa ioien eta biomolekulen presentzia agerian jartzeko
}

\author{
(Luminescence, a suitable tool to visualize ions and biomolecules)
}

\author{
Edurne Avellanal-Zaballa, Jorge Bañuelos*
}

Kimika Fisiko Saila, Zientzia eta Teknologia Fakultatea (UPV/EHU), Leioa, Bizkaia

LABURPENA: Biomolekulen eta ioien detekzio sentikorra eta eraginkorra premiazkoa da biomedikuntzan, ez soilik prozesu biokimikoak aztertzeko, baita gaixotasun mekanismoak ulertzeko eta sendagaiak bilatzeko ere. Eskuragarri dauden detekzio tekniken artean, luminiszentzia baliabiderik aproposenetariko bat da informazio kimiko hori lortzeko seinale analitiko gisa sentikortasun eta espezifikotasun ezin hobeak bermatzen baititu. Fluoreszentzia aldaketei jarraituz aztertu beharreko molekularen presentzia detektatzeaz gainera, beraren kantitatea ere kuantifika daiteke. Beraz, koloratzaileen kimika moldakorraz baliatuz, sentsore fluoreszenteak gara daitezke kromoforo bati aproposa den hartzaile espezifikoak lotuz. Lan honetan, holako sentsoreak diseinatzeko kontuan hartu behar diren irizpide orokorrak aipatzen dira. Azken hori agerian jartzeko, BODIPY koloratzailean oinarritutako bi sentsore fluoreszente deskribatzen dira, katioiak eta aminoazidoak detektatzeko gai direnak. Euren presentzia eta kantitatea aztertzeko fluoreszentzia ahalmena eta kolore aldaketa ikuskatzen dira, hurrenez hurren, biak begi bistaz erraz behatzen diren fenomenoak izanik.

HITZ GAKOAK: luminiszentzia, koloratzaile, sentsoreak.

ABSTRACT: An efficient and high-resolution sensing of biomolecules and ions is of paramount relevance in biomedicine not only to monitor biochemical processes, but also to unravel the underlying mechanisms in diseases and find new drugs against them. Between the tested approaches to this aim, luminescence outstands as a suitable tool to gather such chemical information as an analytical signal, endowed with high sensitivity and specificity. The change of the fluorescence signal allows the visualization of the target molecules and its quantification as well. Therefore, fluorescent sensor can be developed applying dye chemistry, after anchoring a suitable receptor to a given chromophore. Herein, we disclose key guidelines to take into account in the design of such sensors. As a matter of fact, hereafter, we describe two BODIPY fluorophores based sensors to detect cations and amino acids. The monitorization is carried out following the change of the fluorescence efficiency and colour, respectively, being both of them properties easily visualized by the naked eye.

KEYWORDS: luminescence, dye, sensors.

\footnotetext{
* Harremanetan jartzeko / Corresponding author: Jorge Bañuelos. Kimika Fisikoko saila, UPV/EHU, Aptdo. 644 (48080 Bilbao).-jorge.banuelos@ehu.eus - https://orcid.org/0000-0002-8444-4383.

Nola aipatu / How to cite: Avellanal-Zaballa, Edurne; Bañuelos, Jorge (2020). «Luminiszentzia, baliabide aproposa ioien eta biomolekulen presentzia agerian jartzekow; Ekaia, 38, 2020, 215-230. (https://doi.org/10.1387/ekaia.21587).

Jasoa: 22 martxoa, 2020; Onartua: 06 maiatza, 2020.

ISSN 0214-9001 - eISSN 2444-3255 / (c) 2020 UPV/EHU
}

(c) (i) () Obra hau Creative Commons Atribución 4.0 Internacional-en lizentziapean dago 


\section{SARRERA}

Biomolekulen eta ioien detekzio azkarra, sentikorra eta ez-inbaditzailea oso garrantzitsua da gizakien gorputzean gertatzen diren hainbat prozesu biokimiko ikuskatzeko eta ulertzeko [1,2]. Informazio kimiko hori gaixotasunen jatorriarekin eta mekanismoarekin erlazionatu dago eta, bide batez, sendagai berrien ikerkuntza eta sorrera ahalbidetzen du [3]. Prozesu biologikoetan zein medikuntza arloan oso interesgarria da ingurune zelularrean gertatzen diren ioien (batez ere katioiak) kontzentrazio-gradienteak ezagutzea. Izan ere, katioiek (hala nola, protoiak, sodioa, magnesioa, kaltzioa, zinka, magnesioa edo burdina) hainbat prozesutan parte hartzen dute: nerbio eta neuronen komunikazio mekanismoetan, giharren uzkurduran, aktibitate zelularraren modulazioan, homeostasian, edo entzimen mekanismo katalitikoan eta metabolismoan, besteak beste [4]. Gainera, halako katioi batzuk sendagai gisa ere erabil daitezke; adibidez, depresioaren aurka (litioa) edo odolaren presioa kontrolatzeko (potasioa). Noski, katioi astunen (merkurioa, beruna, kadmio) detekzioa ere oso garrantzitsua da, izaki bizidunentzat kaltegarriak dira eta [5]. Bestalde, biomolekulen artean, aminoazidoen (AA) detekzioa ere premiazkoa da [6]. Ez soilik proteinen osagai nagusiak direlako, hainbat gaixotasunekin eta osasunarekin oro har duten zerikusi nabarmenagatik ere. Izan ere, aminoazidoen gehiegia edo falta Alzheimerrarekin, sistema immunologikoan toxinei aurre egiteko, minbiziarekin edo oro har gaixotasun kardiobaskularrekin lotuta baitago [7]. Hori guztia kontuan hartuz, erraz uler daiteke biosentsore sentikor eta espezifikoak garatzeko ikerkuntzan egiten ari diren ahalegin ugariak, ingurune zelularrean informazio kimikoa era zuzenean eskuratzen ahalbidetzen dutelako [8].

Gaur egun aurreko xedea lortzeko hainbat teknika eta metodo analitiko (elektrokimika, espektroskopia, erradiazio nuklearra eta abar) erabiltzen dira. Haien artean, luminiszentzia propietatea erabat egokia da bilatzen den informazio kimikoa (biomolekulen eta katioien presentzia eta kantitatea) informazio analitiko (detekzioa seinale fluoreszente gisa) bihurtzeko [9]. Luminiszentzia molekularen elektroiak kitzikatu ostean argia edo fotoia igortzeko gaitasuna da. Kitzikapen prozesuaren arabera luminiszentzia mota bat baino gehiago daude: erreakzio kimikoen bidekoa (kimioluminiszentzia), korronte elektrikoaren bidezko (elektroluminiszentzia) edo erradiazioaren bidezkoa (fotoluminiszentzia edo fluoreszentzia) [10]. Sentsoreak garatzeko gehien erabiltzen den luminiszentzia mota fluoreszentzia da [11], batez ere azken urteotan mikroskopia fluoreszentean egindako aurrerapausoei esker. Teknika horren bidez bioirudia garatu da non fluoreszentzia seinalea sentikortasun handiz erraz ikusten den, hau da, molekula baten igorpena detekta eta bereiz daiteke (nanoskopia edo super-erresoluzioko mikroskopia) [12,13]. Teknologia horrek eskaintzen duen bereizmen espazial eta denbora-bereizmen paregabeek fluoreszentziaren erabilera nabarmenki bultzatu dute (detekzio prozesuetan sentikortasun oso altua lor- 
tuz) eta inguruko bioorganuluetan albo-efektu edo -kalterik izan gabe, bai in situ zein in vivo esperimentuetan [14].

Sentsore fluoreszente eraginkorra eta arrakastatsua lortzeko diseinu molekularra ezinbestekoa da [15]. Oro har, sentsoreak oinarrizko bi zati eduki behar ditu; fluoreszentea den kromoforoa (fluoroforoa), detekzio prozesua agerian jartzeko eta seinalea eskuratzeko, eta hartzaile aproposa aztertzen den molekula itua harrapatzeko (1. irudia). Oro har, fluoroforo gisa, molekula organikoak erabiltzen dira, hartzaileak kimikoki eransteko beren molekula-egitura erraz eralda daitekeelako, kimika organikoaren baliabide sintetikoez baliatuz [16]. Hartzailearen funtsa bikoitza dela aipatu beharra dago. Alde batetik, detektatu nahi den molekularekiko edo ioiekiko afinitate handia erakutsi behar du. Beste alde batetik, fluoroforoaren ezaugarri fotofisikoak, bereziki propietate fluoreszenteak, nabarmenki eraldatu behar ditu (adibidez, hartzailetik kromoforora elektroi transferentzia sorrarazi, edo haien elektroihodeien arteko interakzio erresonantea ahalbidetu) [17]. Are gehiago, sortutako aldaketa horrek moldakorra izan behar du, behin molekula edo ioia hartzailearekin elkartuz gero detekzio prozesuaren monitorizazioa ahalbidetzeko (eskuarki fluoreszentzia ahalmena edo kolorearen aldaketa dela medio), hots, bilatzen den informazio kimikoa informazio analitiko bilakatzeko (1. irudia).

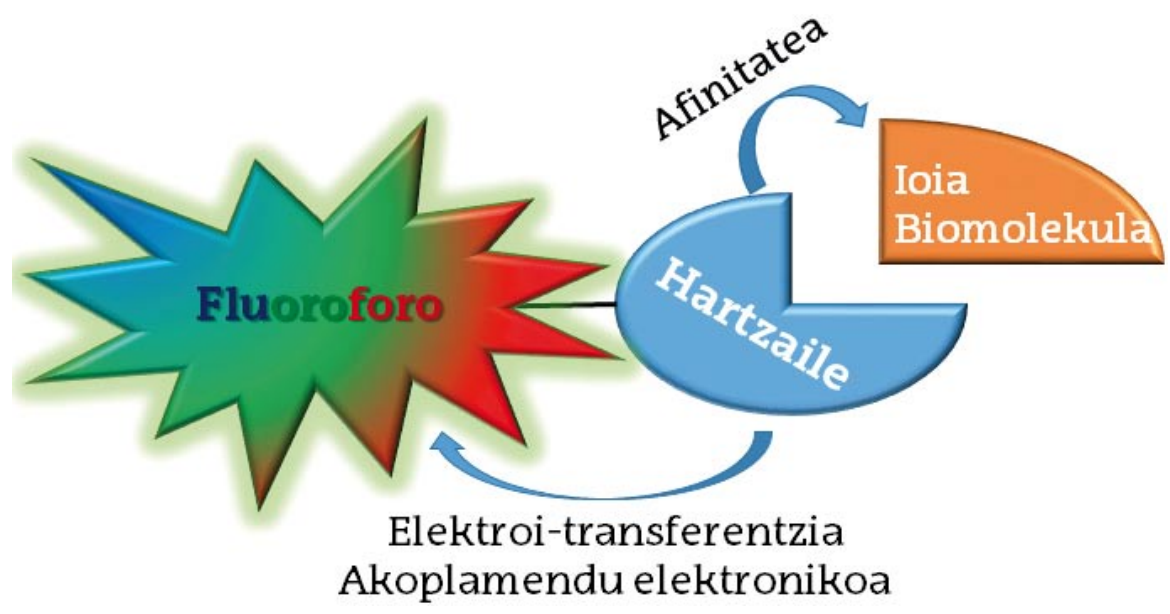

1. irudia. Sentsore fluoreszentearen oinarrizko osagaiak eta haien artean gertatu behar diren prozesu garrantzitsuenak.

Lan honetan, katioiak eta tiol taldea daramaten aminoazidoak detektatzeko gai diren sentsore fluoreszenteak aurkezten dira. Hain zuzen ere, haien diseinuak eta detekzio mekanismoak aztertzen dira. Kromoforo fluoreszente gisa boro dipirrometeno (4,4-difluoro-4-bora-3a,4a-diaza-s-indazenoa, BODIPY) izeneko koloratzaile organikoa aukeratu dugu (2. iru- 
dia) $[18,19]$. Fluoroforo hori bere izaera organikoa dela eta, ezaugarri espektroskopiko paregabeak erakusteaz gain, biobateragarria da, eta oso egonkorra (bai kimikoki zein energia handiko erradiazioaren aurrean). Hala ere, konposatu organiko horren abantaila nagusia da sintesi erraza eta egitura aldakorra dituela [20]. Hots, prozedura sintetiko ugari erabil daitezke kromoforoaren posizio zehatzetan talde funtzional sorta zabala lotzeko. Era berean, ordezkatzaile horiek ezaugarri fotofisikoak eta, hortaz, fluoreszenteak ere guztiz alda ditzakete, hala nola banden posizioa edo intentsitatea. Arrazoi horiengatik guztiengatik, ioi eta molekulen detekziorako kromoforo gisa BODIPYa aukeratu zen; izan ere, hainbat sentsore fluoreszente lortzeko sarritan erabili ohi da [21,22].

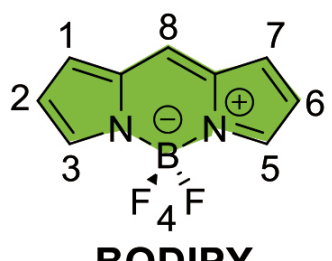

2. irudia. BODIPY molekularen egitura kimikoa eta posizioen zenbakitzea (IUPACen arabera).

Molekula abiapuntutzat harturik, hurrengo lerroetan zehar bi sentsore fluoreszente aurkeztuko dira. Bata on-off sentsore gisa katioiak detektatzeko, elektroi-transferentzia prozesu baten ondorioz. Bestea, aldiz, tiola daramaten aminoazidoentzat, hala nola zisteina (CYS), homozisteina (HCYS) eta glutationa (GSH), sentsore ratiometriko gisa, igorpen espektroetan gertatzen diren aldaketei (igorpen hazkunde/beherakada) jarraituz. Lehendabizi, BODIPYan oinarritutako sentsore fluoreszenteak garatzeko kontuan hartutako irizpideak azaltzen dira (batez ere hartzailearen aukeraketa eta horren kokapena kromoforoan). Ondoren, espektroskopia eta kimika konputazionala erabilita sentsore horien detekzio mekanismoak deskribatzen dira, bilatzen den informazio kimikoa seinale analitiko gisa eskuratzeko, katioien eta aminoazidoen presentzia agerian jarriz eta haien inguruneko kontzentrazioa zehaztuz.

\section{SENTSORE FLUORESZENTEAK}

\subsection{On-off sentsoreak eta sentsore ratiometrikoak}

1. irudiaren jarraibideak kontuan hartuz, aztergai den molekularako sentsore fluoreszente egokia eskuratzeko, fluoroforari hartzaile aproposa lotu behar zaio kimikoki. Hartzaileek sortutako prozesu fotofisikoek kromoforoaren fluoreszentzia seinalearen gainean aldaketak eragiten dituzte, baina 
ohikoenak hauek dira: argiaren bidez induzitutako elektroien transferentzia (photoinduced electron transfer, PET) eta akoplamendu elektronikoa [23]. Era honetan on-off sentsoreak eta sentsore ratiometrikoak garatzen dira, hurrenez hurren. On-off sentsoreak batez ere katioiak detektatzeko erabiltzen dira [24]. Horretarako, hautatutako hartzaileek elektroi emaile ahaltsuak izan behar dituzte, positiboki kargatutako katioiekin erraz eta azkar lotzeko. Izaera elektroniko horrengatik, hartzaileak kromoforoan PET prozesua sorrarazten du (hartzailetik kromoforora elektroi baten saltoa termodinamikoki faboratuta dago), eta azken horren seinale fluoreszentea desagerrarazten du (off egoera, 3A. irudia) [25]. Baina ingurunean katioiak daudenean, hartzailearekin elkartzen dira, eta ondorioz azken horren ahalmen elektroi-emailea murrizten da. Horren ondorioz, PET prozesuaren probabilitatea zeharo murrizten da (ikuspuntu energetikotik hartzaileak kromoforoari elektroi bat transferitzea ezinezkoa da) eta kromoforoaren fluoreszentzia berreskuratzen da (on egoera, 3A irudia). Hortaz, ingurunean katioirik ezean sentsore horien fluoreszentzia itzalita dago, baina haien aurrean fluoreszentzia pizten da [26]. Ahalmen fluoreszentearen aldaketa bortitz hori dela eta, mikroskopio fluoreszentean katioiaren monitorizazioa nabaria eta eraginkorra da.
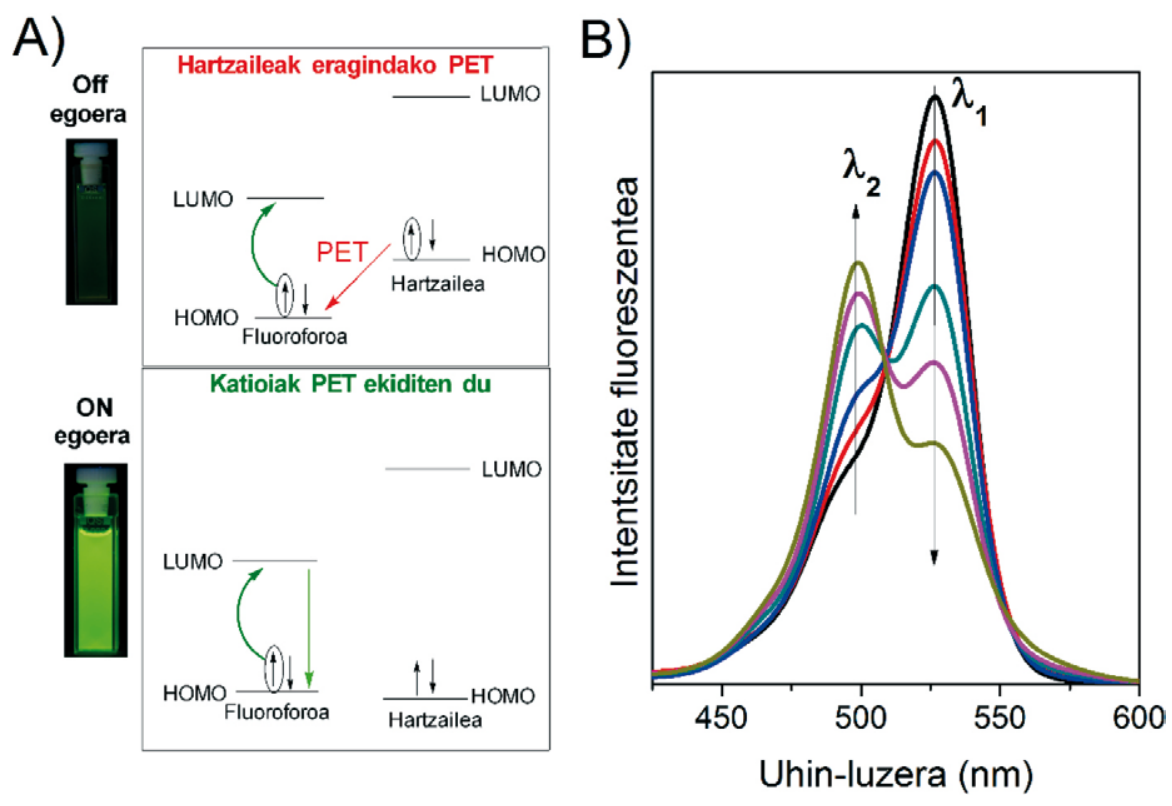

3. irudia. (A) On-off sentsoreen eta (B) sentsore ratiometrikoen seinale fluoreszentean gertatzen diren aldaketak aztergai den katioi eta biomolekularen detekzioa ahalbidetzeko, hurrenez hurren. HOMO (Highest Ocuppied Molecular Orbital) eta LUMO (Lowest Unocuppied Molecular Orbital). B ataleko geziek detektatu nahi den molekula ituaren kantitatea handitzen den heinean (kolore ezberdinez) espektroan gertatzen diren aldaketak adierazten dituzte. 
Sentsore ratiometrikoetan, ordea, aukeratutako hartzaileak talde funtzional aproposak ditu detektatu nahi den molekularekin kimikoki erreakzionatzeko (3B irudia) [27]. Gainera, hartzailea eta kromoforoaren arteko akoplamendu elektronikoari esker, azken horren banda espektralak, eta, beraz, baita fluoreszentzia ere, alde gorrira lerrokatzen dira $\left(\lambda_{1}, 3 \mathrm{~B}\right.$ irudian). Behin detektatu nahi den molekulak hartzailearekin erreakzionatuz gero, haien elkarrekintza erresonantea kromofoarekin murrizten da eta uhin-luzera baxuagoetan banda espektral berriak agertzen dira $\left(\lambda_{2}, 3 \mathrm{~B}\right.$ irudian). Hau da, aztertzen ari garen molekula sentsorearen inguruan dagoenean, azken horren jatorrizko igorpena uhin-luzera altuagoetan gradualki murrizten da, eta neurri berean uhin-luzera baxuko igorpena hazten da (3B irudia). Bi igorpen banden aldaketa horrek, erlatiboak zein kontrakoak (hortik dator ratiometriko izenaren jatorria), detektagarria den molekularen kantitatearen kuantifikazio zehatza ahalbidetzen du. Are gehiago, fluoreszentziaren kolorea ere aldatzen da, eta hala detekzioa errazten eta nabaria izanez.

\subsection{Sentsoreen diseinu molekularra}

Katioiak detektagarriak izateko BODIPY bati bere boro zubian elektroi-emaile den talde bat txertatu zaio, fluor atomoak ordezkatuz (4A irudia). Boro atomoan sortutako eraztun espiraniko horretan amino talde batek ez dauka ordezkatzailerik; beraz, elektroi-bikote askea dauka, eta katioiekin elkartzeko hartzaile aproposa da. Gainera, boroan dagoen taldea elektroiaberatsa da, fenilo taldearen bitartez aminak elektronikoki lotuta daudelako. Ondorioz, hartzaileak bere osotasunean elektroi-emaile izaera dauka eta elektroi-transferentziazko prozesuak (esate baterako, PET) sortzeko gai izan daiteke. Horri esker, ahalmen fluoreszentearen aldaketei jarraituz gero katioien presentzia agerian jar daiteke, on-off sentsore berri baten sorkuntza bultzatuz.

A)

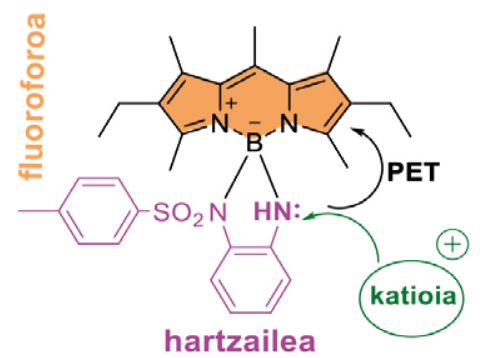

B)

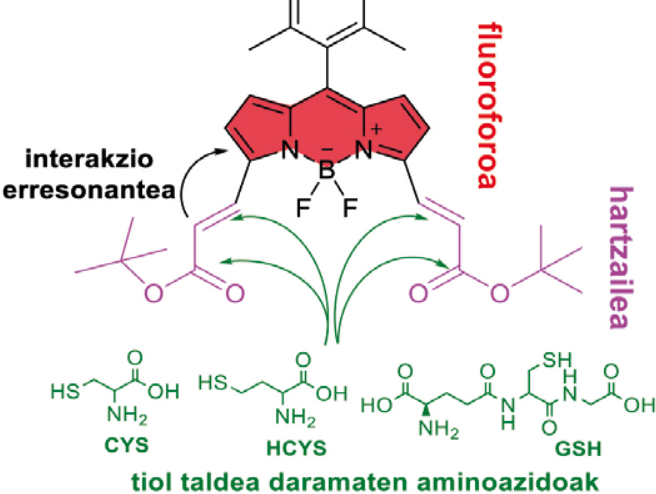

4. irudia. BODIPYan oinarritutako sentsore fluoreszenteen molekula-egiturak katioiak (A, N-BODIPY) eta tiol taldea daramaten aminoazidoak (B, 3,5-diesterBODIPY) detektatzeko. Sentsoreen atalak eta detekzioguneak nabarmentzen dira. 
Bestalde, tioldun aminoazidoak detektatzeko hartzaile gisa BODIPYaren 3 eta 5 posizioetan ester asegabeak txertatu dira (4B irudia). Tiol taldea nukleozalea da, eta karbonilo eta binilo taldeekin erraz erreakzionatzen du. Are gehiago, elkarrekintza erresonantearen bidez ester horiek BODIPYaren kromoforoarekin elektronikoki akoplatzen dira, sistema konjokatua hedatuz eta banda espektralak batokromikoki (uhin-luzera handiagoetara) lerrokatuz. Behin aminoazidoa detektatzen denean, sistemaren hedapena aldatzen da, eta banda espektral berriak agertzen dira. Horri esker sentsore ratiometriko honetan, aminoazidoen presentzia erraz beha daiteke agerian gertatzen den fluoreszentziaren kolore aldaketaren ondorioz, eta, igorpen banden arteko intentsitate aldaketak direla medio, kuantifikazioa aurrera eramatea ere posiblea da.

Sentsore horien sintesiaren xehetasunak, purifikazioa eta molekula-egituraren karakterizazioa aldez aurretik argitaratu dira [28, 29].

\subsection{Katioien detekziorako sentsorea}

Katioien presentzia agerian jartzeko erabilitako sentsorea 4A irudian agertzen den koloratzailea izan zen (hemendik aurrera N-BODIPY). Bere banda espektralen posizioak jatorrizko BODIPYren (aminodun zikloaren ordez boro zubian fluor atomoak dituena, ikusi 2. irudia) bandekin alderatuta antzeko uhin-luzeretan agertzen dira, hots, absortzioa $525 \mathrm{~nm}$ ean eta fluoreszentzia $540 \mathrm{~nm}$-ean. Hala ere, N-BODIPYaren ahalmen fluoreszentea oso baxua da ( $<\% 1$ vs \% 84). Beraz, boroan txertatutako elektroi-emaile taldeak ez-erradiatzaile den prozesuren bat sorrarazten omen du, eta horregatik fluoreszentzia guztiz galtzen da. Horren zergatia ulertzeko, kalkulu mekanokuantikoak egin ziren, eta orbital molekularren $(\mathrm{OM})$ energia-banaketa bereziki aztertu zen (5. irudia). Oro har BODIPYaren HOMO (Highest Ocuppied Molecular Orbital) eta LUMO (Lowest Unocuppied Molecular Orbital) orbitalak ikusgaiko absortzio eta igorpen trantsizioen arduradunak dira. Baina ezustean N-BODIPYan HOMO orbitala boroari lotuta dagoen atalean kokatzen da, trantsizioaren OM arduradunak HOMO-1 eta LUMO izanik (5A irudia). Orduan, kitzikapenaren ostean elektroiak HOMO-1 orbitaletik LUMOra salto egingo du, eta HOMO-1 erdi hutsik geratzen da. Horrela, PET prozesua termodinamikoki posible bihurtzen da, eta HOMO orbitalean dagoen elektroiak HOMO-1-era salto egin dezake, eta hala LUMO orbitalean dagoen elektroiaren itzulera ekidin. Ondorioz, elektroi transferentzia baten aurrean gaude (PET erreduzitzailea) aminodun eraztunetik BODIPYra gertatzen dena, eta horixe da, hain zuzen ere, fluoreszentziaren galeraren arduraduna [30]. 


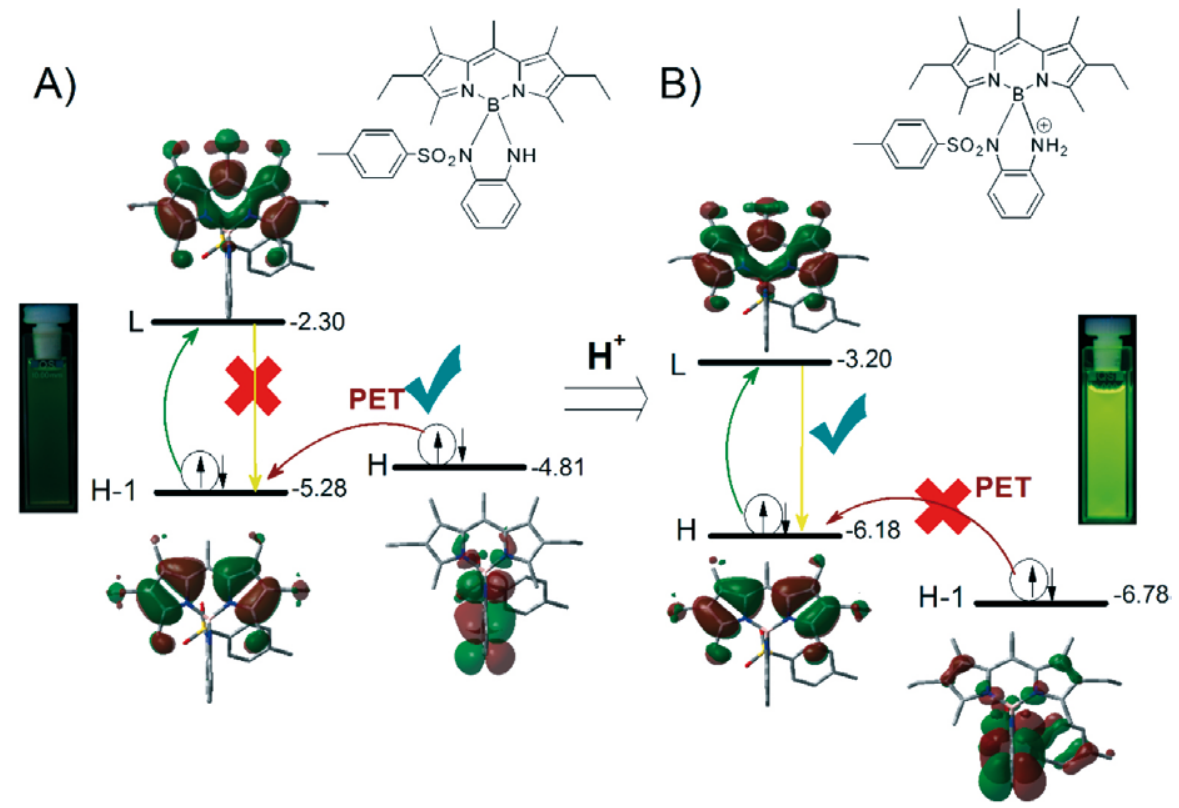

5. irudia. Kalkulu teorikoen bitartez aurresandako orbital molekularren energia diagrama (eV-etan) protoiarekin elkartu baino lehen (A) eta ostean (B). HOMO eta LUMO orbitalak adierazteko $\mathrm{H}$ eta L erabili dira, eta $\mathrm{H}-1$ HOMOren azpian dagoen orbital molekularra da. Orbital molekularren mapek dentsitate elektronikoa non den adierazten dute.

Emaitza teoriko horien aurrean, hartzaile den aminan protoi bat gehitu zen sentsore honen portaera eta bideragarritasuna ikuspuntu teorikotik aurresateko (5B irudia). Protoiaren presentziak OM banaketa berrantolatzen du. Egoera berri honen aurrean, HOMO eta LUMO orbitalak N-BODIPYn kokatzen dira (hasieran espero zen egoera energetikoa), eta HOMO-1 boroan dagoen aminodun eraztunean agertzen da. Hau da, protoiaren presentziagatik, azken talde horren ahalmen elektroi-emailea asko murrizten da, eta PET prozesua ez da inondik inora termodinamikoki posiblea izango (langa energetikoa oso altua da, $0.6 \mathrm{eV}$-ekoa). Beraz, kitzikatu ostean LUMOn dagoen elektroia HOMOra itzul daiteke, eta fluoreszentzia berreskuratzen da, hartzailea protoiarekin elkartzean boroan dagoen taldeak ez daukalako inongo eraginik BODIPYren gainean. Ondorioz, protoiak N-BODIPYren fluoreszentziaren gainean aldaketa nabarmenak sortzen ditu, eta katioien sentsore gisa aproposa izan daiteke.

Aurrekoa teorikoki frogatu ostean, katioi desberdinen aurrean fluoreszentzia ahalmenaren joera esperimentalki aztertu zen (6. irudia). Hasierako 
hipotesia honako hau da: holako katioi batek tosilo talderik gabeko aminarekin elkartzean, azken horren elektroi-ahalmena murriztuko litzatekeela, eta, horrekin batera, PET gertatzeko probabilitatea ere bai, fluoreszentzia bide batez berreskuratuz. Katioi monobalenteak $\left(\mathrm{Li}^{+}, \mathrm{Na}^{+}\right.$eta $\left.\mathrm{K}^{+}\right)$eta dibalenteak $\left(\mathrm{Ca}^{2+}, \mathrm{Mg}^{2+}, \mathrm{Ni}^{2+}\right.$ eta $\left.\mathrm{Zn}^{2+}\right)$ aztertu zirenean, ez zen fluoreszentzian aldaketa nabarmenik behatu, ezta bilatzen zen fluoreszentzia seinalearen gorakada ikusi ere. Halere, $\mathrm{Co}^{+2}, \mathrm{Fe}^{+2}$, katioi tribalenteak $\left(\mathrm{Fe}^{+3}\right.$ eta $\left.\mathrm{Cr}^{3+}\right)$ eta protoiak gehitzean, fluoreszentziak gorakada handia egiten zuen; $\mathrm{Cr}^{+3}$ eta protoiekin batez ere, halako moldez non seinalea 20 eta 40 aldiz handitu zen, hurrenez hurren. Beraz, diseinatutako N-BODIPY hori karga altuko katioiekiko sentikorra da. Hots, detekziorako beharrezkoa den elkarrekintza elektrostatikorako, katioiaren karga positiboa zenbat eta altuagoa izan hobe. Adibide gisa, 7. irudian $\mathrm{Cr}^{3+}$ igorpen espektroen joera erakusten da, katioiaren kantitatea (titrazioa) handitzen denean. Protoien kasuan detekzio oso ona da katioi horren tamaina txikia delako, oztopo esterikoa ekidinez, eta amina taldeak protoia harrapatzeko afinitate handia duelako. Nahiz eta kantitate txikiak bota (mikromolar batekoak, hortxe), horiek nahikoak dira fluoreszentzia handitzeko, aldaketa hori katioiaren kontzentrazioarekiko gero eta handiagoa izanik [28].

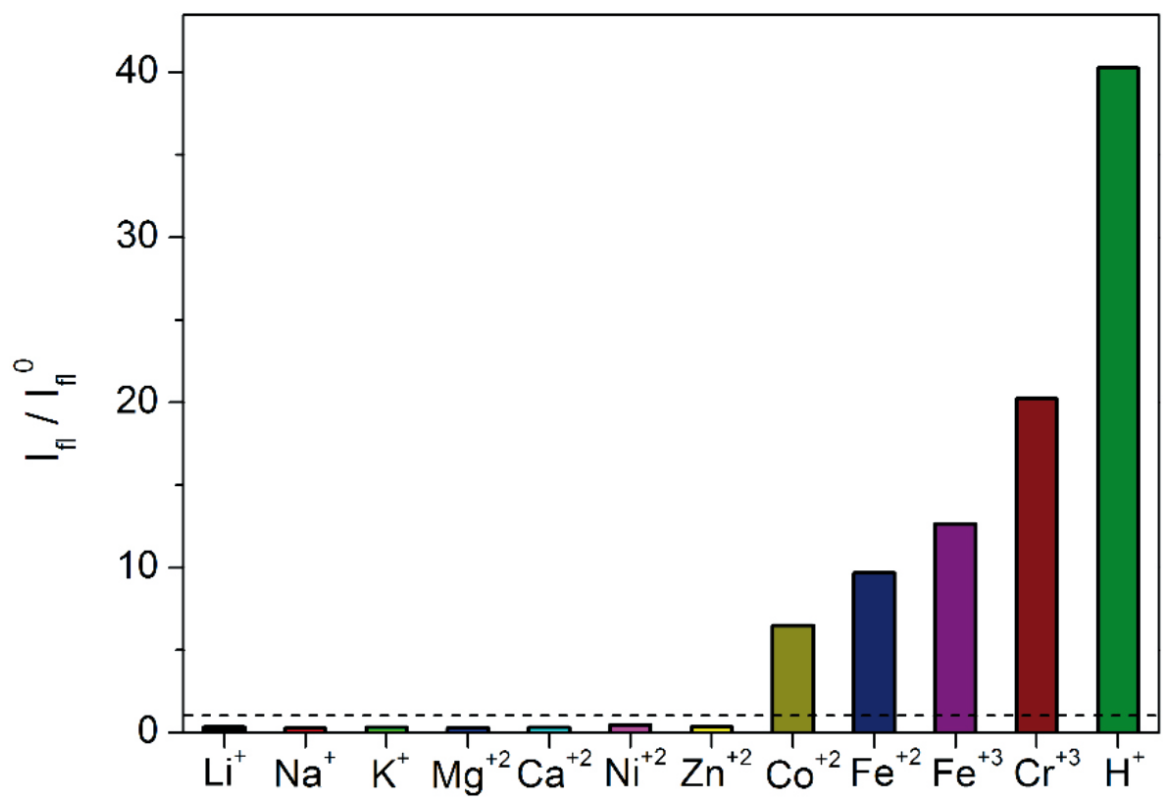

6. irudia. N-BODIPYren intentsitate fluoreszentea katioi sobera dagoenean disoluzioan $\left(\mathrm{I}_{\mathrm{fl}}\right)$ zati intentsitate fluoreszentea katioirik gabe inguruan $\left(\mathrm{I}_{\mathrm{fl}}{ }_{\mathrm{fl}}\right)$ hainbat katioitarako (koloratzailearen kontzentrazioa: $4 \mu \mathrm{M}$, eta katioiarena: $0.1 \mathrm{mM})$. 
Laburbilduz, diseinatutako N-BODIPY protoiak eta karga altuko katioiak detektatzeko aproposa da, erantsitako hartzaileak suertatutako PET prozesuari esker fluoreszentzia eraginkortasunez desaktibatzen duelako (off egoera). Baina, behin hartzaileak holako katioi bat harrapatzen duenean, PET prozesua deuseztatzen da, eta fluoreszentzia berreskuratzen da (on egoera).

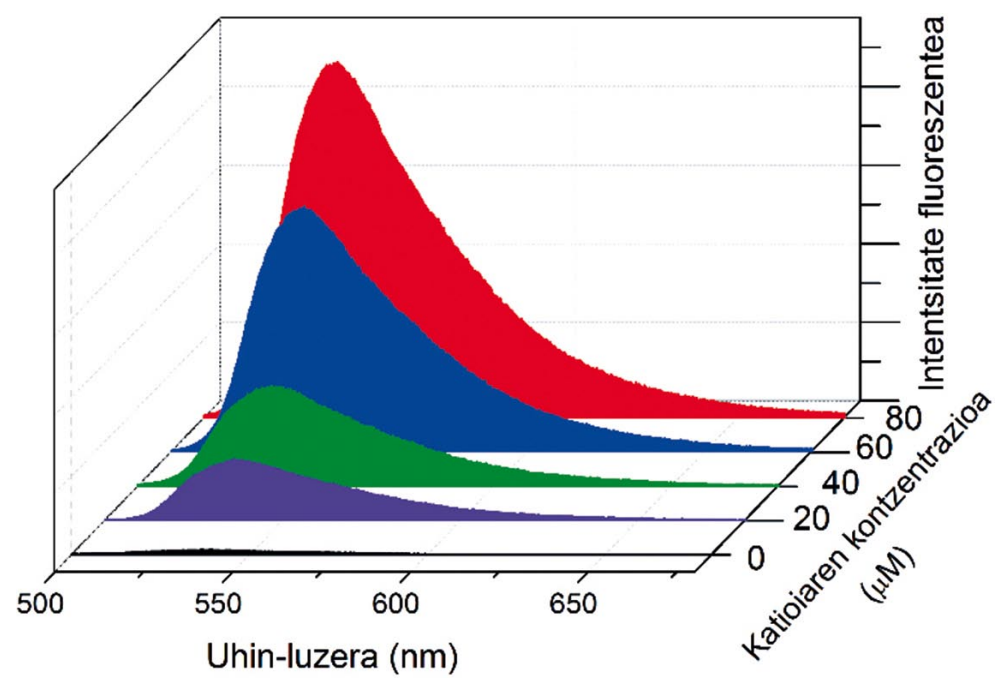

7. irudia. N-BODIPYren fluoreszentzia espektroak $\mathrm{Cr}^{3+}$ katioi kantitate desberdinak gehitu eta gero.

\subsection{Biomolekulen detekziorako sentsorea}

Sentsore hau lortzeko BODIPYren 3 eta 5 posizioetan bi ester talde eransten dira binilo taldeen bidez (3,5-diesterBODIPY, 4B irudia). Txertatutako ester asegabeen elkarrekintza erresonantearen ondorioz, BODIPYren banda espektralak alde gorrira nabarmenki lerrokatzen dira. Hain zuzen ere, absortzioa $590 \mathrm{~nm}$-ean eta fluoreszentzia $600 \mathrm{~nm}$-ean kokatzen dira (8. eta 9. irudiak). Tiol taldea daramaten aminoazidoen presentziak (CYS, HCYS eta GSH) banda espektraletan aldaketa itzelak eragiten ditu, eta, hala, uhin-luzera baxuagoetan trantsizio berriak sorrarazten, fluoreszentziaren kasuan batez ere (8. eta 9. irudiak). Izan ere, aminoazidoaren kontzentrazioa baxua denean (mikromolar batekoa, hortxe) banda berri bat agertzen da bai absortzioan (550 nm-ean) zein fluoreszentzian (560 nm-ean). Hemendik aurrera AA kontzentrazio gehiago gehituz gero (milimolarreraino), bi espektroetan beste banda berri bat (515 nm-ean absortzioan eta $525 \mathrm{~nm}$-ean fluoreszentzian) agertzen da. Banda berri horien 
agerpenak uhin-luzera baxuagoetan sistema konjokatuaren hedapena aldatzen ari dela adierazten du, AAk koloratzailearen ester asegabeekin duen elkarrekintzaren ondorioz. Hots, BODIPYren 3 eta 5 posizioetan txertatutako ordezkatzaileak, zeinak hartzaile gisa jokatzen baitu, nukleozaleekin (AAen tiola) erreakzionatzeko talde aproposak daramatza (binilo eta karbonilo). Elkarrekintza karboniloarekin gertatzen bada (4B irudia), horrek jada ez du parte hartzen sistema konjokatuan, eta detektatzen diren bandak BODIPYk soilik biniloekiko duen akoplamenduari dagozkio (560 nm-eko igorpen banda, 8. irudia). Elkarrekintza biniloarekin gertatzen bada (4B irudia), ostera, 3 eta 5 posizioan dagoen ordezkatzailea ez da BODIPYrekin elektronikoki akoplatzeko gai, eta azken horren jatorrizko banda berreskuratzen da (525 nm-eko igorpena, 8. irudia). Beraz, 3,5-diesterBODIPY sentsore ratiometriko gisa erabiltzeko aproposa da, tioldun aminoazidoak detektatzeko hiru aukera aurkezten baititu: fluoreszentzia beherakada $(600 \mathrm{~nm})$, edo hazkundeak $(560 \mathrm{~nm}$ zein $525 \mathrm{~nm})$ (9. irudia). Are gehiago, joera espektral horien ondorioz AAen detekzioa erraz egin daiteke begi hutsez, kontzentrazioa handitzen den heinean disoluzioaren igorpen-kolorea desberdina baita (gorritik laranjara, eta gero horira, 9. irudia). Horregatik, sentsore hau, ratiometrikoa izateaz gain, kolorimetrikoa ere badela esan dezakegu [31].

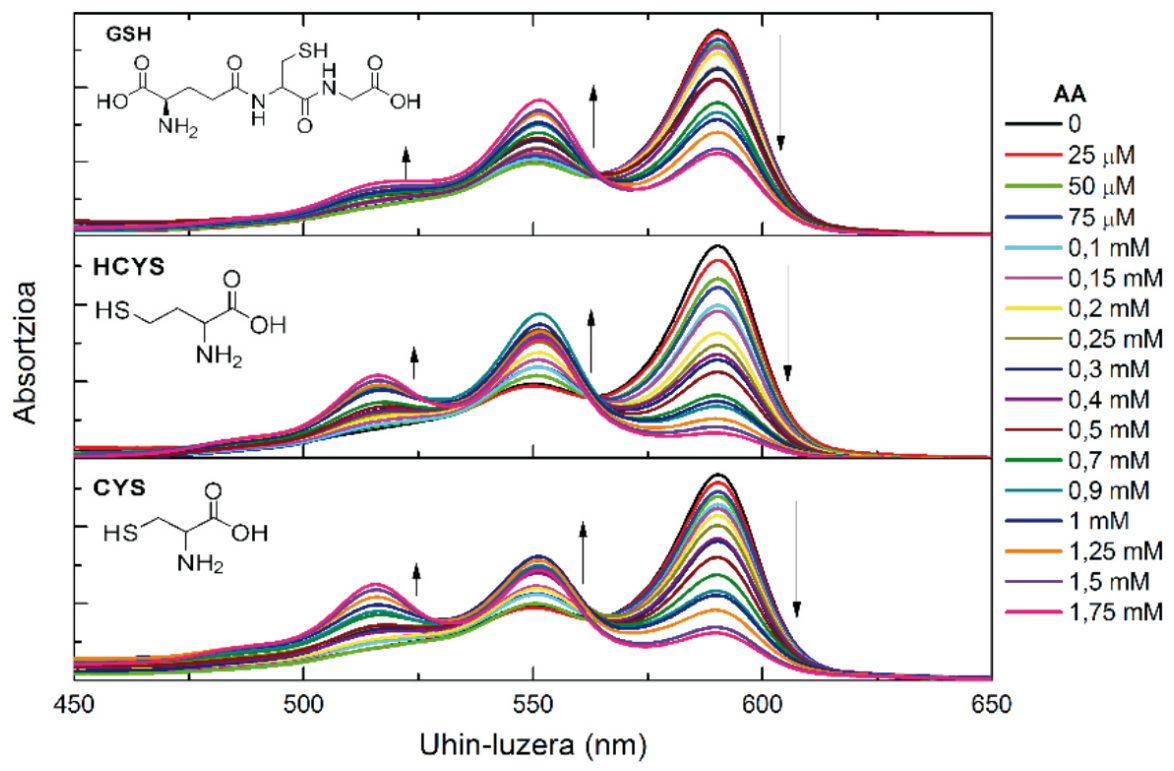

8. irudia. 3,5 -diesterBODIPYren ( $2 \mu \mathrm{M}$-eko kontzentrazioa) absortzio espektroak ingurunean tioldun aminoazidoen (AA) kantitate ezberdinak gehitu eta gero. Neurketak ingurune biologikoaren baldintzak simulatzeko etanol/HEPES buffer urtsu nahasteetan (1:1) aurrera eraman dira. 


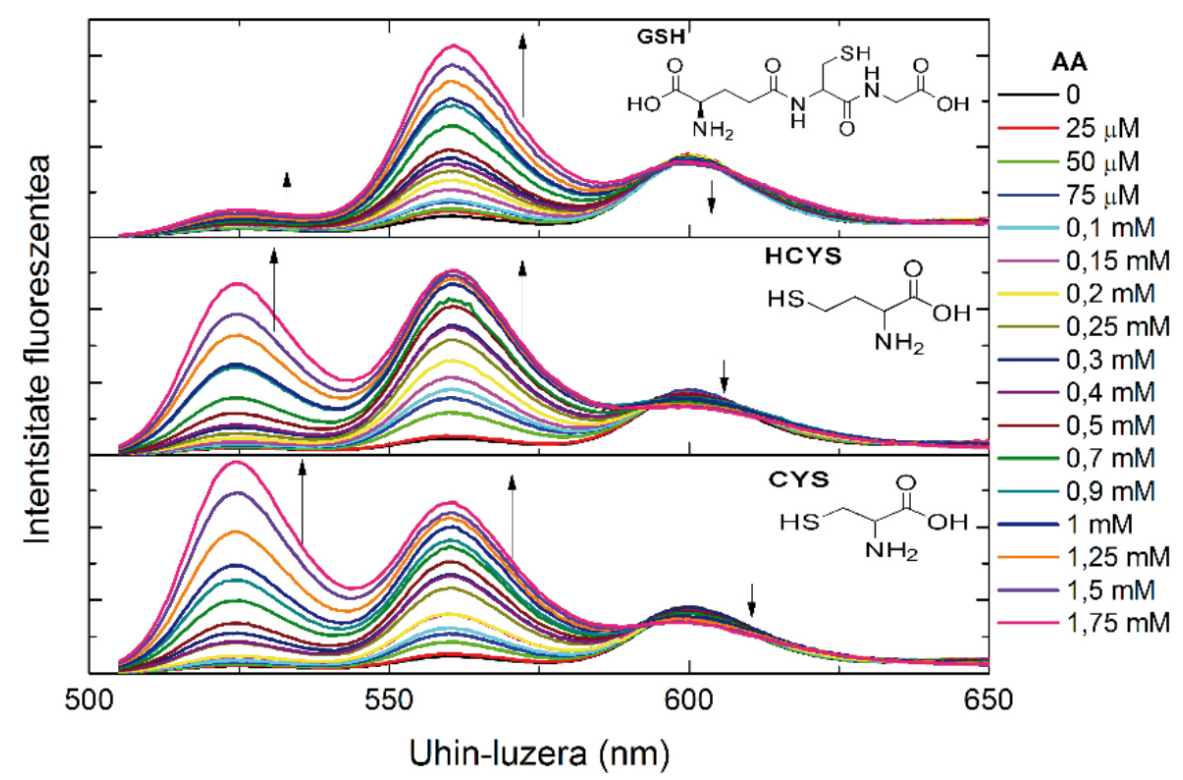

9. irudia. 3,5-diesterBODIPYren ( $2 \mu \mathrm{M}$-eko kontzentrazioa) fluoreszentzia espektroak ingurunean tioldun aminoazidoen (AA) kantitate ezberdinak gehitu eta gero. Neurketak ingurune biologikoaren baldintzak simulatzeko etanol/HEPES buffer urtsu nahasteetan (1:1) aurrera eraman dira.

Detekzioa erraza eta azkarra izateaz gain, hiru kanalak (edo uhin-luzera) erabiliz eta sentikortasun itzelarekin (mikromolar azpitik) AAen kontzentrazioa kuantifikatzea posiblea da. Aukera hori erakusteko 10. irudian aurkezten da hiru uhin-luzera adierazgarritan zein den intentsitate fluoreszentearen aldaketa AA bakoitzaren kontzentrazioarekiko. Kolore aldaketaz gain, irudian beha daiteke nola $525 \mathrm{~nm}$-ean eta $560 \mathrm{~nm}$-ean gertatzen diren fluoreszentzia handipenak AA detektatzeko eta kuantifikatzeko kanalik egokienak diren. Gainera, BODIPYn oinarritutako sentsore fluoreszente hori sentikorragoa da CYS eta HCYS kasuetarako GSHrako baino, non intentsitate fluoreszentearen aldaketak AA kontzentrazioarekiko ahulagoak diren (10. irudia) [31]. Litekeena da sentikortasun desberdintasun hori AAren tamainarekin erlazionatuta egotea. Hau da, GSH gainerako AAak baino handiagoa denez, beraren tiol taldeak oztopo esteriko handiagoa sor dezake hartzailearekin erreakzionatzean. 

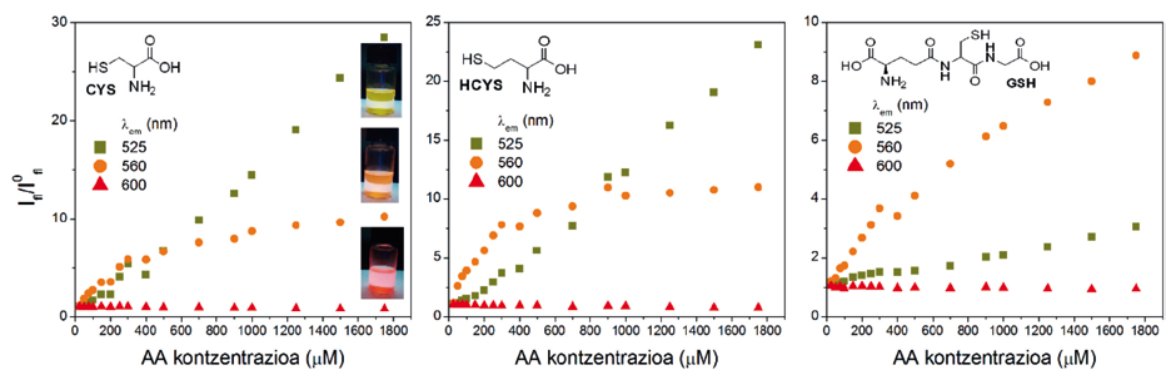

10. irudia. 3,5-diesterBODIPYren intentsitate fluoreszentearen aldaketa 525, 560 eta 600 nm-ean aztertutako hiru aminoazidoen (CYS, HCYS eta GSH) kontzentrazioarekiko.

\section{ONDORIOAK}

Lan honetan, BODIPY koloratzaile organikoan oinarrituz katioiak eta tioldun aminoazidoak detektatzeko sentsore fluoreszenteak aurkeztu dira. Bereziki diseinu molekularrean eta detekzioa ahalbidetzen duen mekanismo fotofisikoan arreta jarri da. Katioietarako on-off sentsoreak diseinatu eta probatu dira, elektroi-aberatsak diren hartzaileak txertatuz. Ordezkatzaile horien izaera elektronikoari esker elektroi-transferentzia bultzatzen da, BODIPYren fluoreszentzia guztiz deuseztatuz (off egoera). Baina, inguruneko katioia (maila mikromolarrean) hartzailearekin elkartzen denean, aurretik aipatutako PET prozesua eten egiten da, eta fluoreszentzia berreskuratzen da (on egoera), detekzioa ahalbidetuz. Beste alde batetik, tiol taldea daramaten aminoazidoetarako sentsore ratiometrikoak lortu dira. Kasu horretan, BODIPYan talde elektroizalea daraman ordezkatzailea txertatu da. Bi horien arteko elkarrekintza erresonantearen ondorioz banda espektralak alde gorrira lerrokatu dira. Ingurunean holako tioldun AAak badaude (mikromolar azpitik), hartzailearen karbonilo edo binil taldeekin erreakzionatzen dute; ondorioz, sistema konjokatuaren hedapena murrizten da, eta gune espektral laranjan eta horian igorpen banda berriak agertzen dira. Hori dela eta, detekzioa zein kuantifikazioa begi-bistakoa, zehatza eta erraza da, hiru detekzio-kanal (eremu gorriko seinalearen murrizketa edo eremu laranja eta horiko seinaleen handipena) eskuragarri baitaude.

Hala eta guztiz ere, etorkizunerako sentsore fluoreszenteen ezaugarriak are gehiago hobetu behar dira. Alde batetik, ingurune urtsuetan (baldintza fisiologikoak bezala) disolbagarritasuna handitu behar da, eskuarki koloratzaile organikoak (BODIPY bezala) hidrofoboak baitira. Bestalde, detekzio-muga maila nanomolarrera murriztea komenigarria izango litzateke, sentsore horien sentikortasuna hobetuz. Erronka nagusia espezifikotasuna hobetzean datza, beste ioi edo molekulen interferentziak ekidinez. Hots, 
soilik aztertzen ari den katioia edo biomolekula detektatzeko gai diren sentsoreak garatu behar dira, nahiz eta ingurunean antzeko ioi edo molekulak egon.

\section{ESKER ONAK}

Artikulu hau Eusko Jaurlaritzak emandako dirulaguntzari (IT912-16 proiektua) eta doktoregai bekari (E.A.Z.) esker gauzatu da. Era berean, S. de la Moya eta M.J. Ortiz ikertzaileei laginen sintesia eskertzen diegu. Eskerrik asko orobat UPV/EHUko SGI/IZO-SGIker zerbitzuari «ARINA» kluster informatikoa erabiltzen uzteagatik.

\section{BIBLIOGRAFIA}

[1] MORAGUES, M.E., MARTÍNEZ-MÁÑEZ, R. eta SANCENÓN, F. 2011. «Chromogenic and fluorogenic chemosensors and reagents for anions». Chemical Society Reviews, 40, 2593-2643.

[2] DAI, J., MA, C., ZHANG, P., FU, Y. eta SHEN, B. 2020. «Recent progress in the development of fluorescent probes for detection of biological thiols». Dyes and Pigments, 177, 108321.

[3] RETTIG, W., STREHMEL, S., SCHRADER, H. eta SEIFERT, H. 2012. Applied fluorescence in Chemistry, Biology and Medicine. Springer, Berlin.

[4] VALEUR, B. eta LERAY, I. 2000. «Design principles of fluorescent molecular sensors for cation recognition». Coordination Chemical Reviews, 205, $3-40$.

[5] LIU, Z., HE, W. eta GUO, Z. 2013. «Recent progress on polymer-based fluorescent and colorimetric chemosensors». Chemical Society Reviews, 40, 1568-1600.

[6] OTTER, D. E. 2012. «Standardized methods for amino acids analysis on food». British Journal of Nutrition, 108, S230-S237.

[7] GEDDES, C.R. eta LAKOWICZ, J. R. 2006. Reviews in Fluorescence 2006. Springer, Berlin.

[8] SINKELDAM, R.W., GRECO, N.J. eta TOR, Y. 2010. «Fluorescent analogs of biomolecular building blocks: design, properties, and applications». Chemical Reviews, 110, 2579-2619.

[9] WU, D., SEDGWICK, A.C., GUNNLAUGSSON, T., AKKAYA, E.U., YOON, J. eta JAMES, T. D. 2017. «Fluorescent chemosensors: the past, present and future». Chemical Society Reviews, 46, 7105-7123.

[10] LAKOWICZ, J.R. 1999. Principles of Fluorescence Spectroscopy. Springer, New York.

[11] SILVA, A.P., GUNARATNE, H.Q., GUNNLAUGSSON, T., HUXLEY, A.J., MCCOY, C.P., RADEMACHER, J.T. eta RICE T.E. 1997. «Signaling 
recognition events with fluorescent sensors and switches». Chemical Reviews, 97, 1515-1566.

[12] BETZIG, E. 2015. «Single molecules, cells and super-resolution optics». Angewandte Chemie International Edition, 54, 8034-8053.

[13] HELL, S.W. 2015. «Nanoscopy with focused light». Angewandte Chemie International Edition, 54, 8054-8066.

[14] VALEUR, B. 2001. Molecular Fluorescence. Wiley-VCH, Weinheim.

[15] RURACK, K. eta RESCH-GENGER, U. 2002. «Rigidization, preorientation and electronic decoupling-the «magic triangle» for the design of highly efficient fluorescent sensors and switches». Chemical Society Reviews, 31, 116127.

[16] MOLINER, F., KIELLAND, N., LAVILLA, R. eta VENDRELL, M. 2017. «Modern synthetic avenues for preparation of functional fluorophores». Angewandte Chemie International Edition, 56, 3758-3769.

[17] ASHER, S.A., SHARMA, A.C., GOPONENEKO, A.V. eta WARD, M.M. 2003. «Photonic crystal aqueous metal cation sensing materials». Analytical Chemistry, 75, 1676-1683.

[18] BOYLE, R.W., MEHL, G.H. eta BENSTEAD, M. 2011. «4,4'-Difluoro-4bora-3a,4a-diaza-s-indacenes (BODIPYs) as components of novel light active materials». Tetrahedron, 67, 3573-3601.

[19] BAÑUELOS, J. 2016. «BODIPY dyes, the most versatile fluorophore ever?». The Chemical Record, 16, 335-348.

[20] BOENS, N., VERBELEN, B., ORTIZ, M.J., JIAO, L. eta DEHAEN, W. 2019. «Synthesis of BODIPY dyes through postfunctionalization of the boron dipyrromethene core». Coordination Chemistry Reviews, 399, 213024.

[21] KOLEMEN, S. eta AKKAYA, E.U. 2018. «Reaction-based BODIPY probes for slective bio-imaging». Coordination Chemistry Reviews, 354, 121-134.

[22] BOENS, N., LEEN, V. eta DEHAEN, W. 2012. «Fluorescent indicators based on BODIPY». Chemical Society Reviews, 41, 1130-1172.

[23] WU, D., SEDGWICK, A.C., GUNNLAUGSSON, T., AKKAYA, E.U., YOON, J. eta JAMES, T.D. 2017. «Fluoresent chemosensors: the past, present and future». Chemical Society Reviews, 46, 7105-7123.

[24] SILVA, A.P., MOODY, T.S. eta WRIGHT, G.D. 2009. «Fluoresent PET (Photoinduced Electron Transfer) sensors as potent analytical tools». Analyst, 134, 2385-2393.

[25] SUNAHARA, H., URANO, Y., KOJIMA, H. eta NAGANO, T. 2007. «Design ans synthesis of a library of BODIPY-based environmental polarity sensors utilizing PET controlled fluorescence ON/OFF switching». Journal of the American Chemical Society, 129, 5597-5604.

[26] ZHOU, Z., YU, M., YANG, H., HUANG, K., LI, F., YI, T. eta HUANG, C. 2008. «FRET-based sensor for imaging chromium (III) in living cells». Chemical Communications, 3387-3389.

[27] LONG, L., LI, X., ZHANG, D., MENG, S., ZHANG, J., SUN, X., ZHANG, C., ZHOU, L. eta WANG, L. 2013. «Amino-coumarin based fluorescence 
ratiometric sensors for acidic $\mathrm{pH}$ and their application for liiving cells imaging». RSC Advances, 3, 12204-12209. [28] Ray, C., Díaz-Casado, L., Avellanal-Zaballa, E., Bañuelos, J., Cerdán, L., García-Moreno, I., Moreno, F., Maroto, B.L., López-Arbeloa, I., de la Moya, S. 2017. «N-BODIPYs come into play: smart dyes for photonic materials». Chemistry European Journal, 23, 9383-9390.

[29] RAMOS-TORRES, A., AVELLANAL-ZABALLA, E., PRIETO-CASTAÑEDA, A., GARCÍA-GARRIDO, F., BAÑUELOS, J., AGARRABEITIA, A.R. eta ORTIZ, M.J. 2019. «FormylBODIPYs by PCC-promoted selective oxidation of $\alpha$-methylBODIPYs. Synthetic versatility and applications». Organic Letters, 21, 4563-4566.

[30] RAY, C., SCHAD, C., AVELLANAL-ZABALLA, E., MORENO, F., BAÑUELOS, J., MAROTO, B.L. eta DE LA MOYA, S. 2019. «Exploring NBODIPYs as privileged scaffolds to build Off/On fluorescent sensors by PET». Proceedings, 41, 54-62.

[31] AVELLANAL-ZABALLA, E., RAMOS-TORRES, A., PRIETO-CASTAÑEDA, A., GARCÍA-GARRIDO, F., BAÑUELOS, J., AGARRABEITIA, A.R. eta ORTIZ, M.J. 2019. «A BODIPY-based fluorescent sensor for amino acids bearing thiol». Proceedings, 41, 18-24. 